\title{
Kajian Pengembangan Lahan Pertanian Tanaman Pangan Berbasis Komoditas Unggulan di Kabupaten Pinrang, Sulawesi Selatan
}

\author{
S. Suryani ${ }^{1}$ \\ Program Studi Magister IImu Perencanaan Wilayah, Sekolah Pascasarjana \\ Institut Pertanian Bogor, Bogor, Indonesia
}

\section{Santun R. P. Sitorus}

Departemen IImu Tanah dan Sumberdaya Lahan, Fakultas Pertanian Institut Pertanian Bogor, Bogor, Indonesia

\section{Untung Sudadi}

Departemen IImu Tanah dan Sumberdaya Lahan, Fakultas Pertanian Institut Pertanian Bogor, Bogor, Indonesia

Artikel Masuk : 5 Juli 2019

Artikel Diterima : 20 Agustus 2020

Tersedia Online : 31 Agustus 2020

\begin{abstract}
Abstrak: Sektor pertanian berperan penting dalam perekonomian Kabupaten Pinrang. Sebagai kawasan lumbung pangan nasional Provinsi Sulawesi Selatan, PDRB sektor pertanian kabupaten ini meningkat dari 4,72 menjadi 7,94 trilyun rupiah pada 2013-2017. Penelitian ini bertujuan untuk mengkaji pengembangan lahan pertanian tanaman pangan berbasis komoditas unggulan di Kabupaten Pinrang, Sulawesi Selatan. Pemanfaatan teknologi geospasial dalam perencanaan pengembangan lahan pertanian di wilayah ini merupakan pendekatan baru dan diharapkan memberikan hasil yang lebih akurat dan mudah dimutakhirkan. Penelitian dilakukan di dua belas kecamatan di wilayah Kabupaten Pinrang sejak September 2018 sampai Juni 2019. Data penelitian meliputi data primer hasil survei lapangan dan data sekunder peta pola ruang RTRW 2012-2032 dari Bappeda serta data luas panen dan produksi tanaman pangan dari BPS Kabupaten Pinrang, karakteristik dan peta penggunaan lahan eksisting dari BBPPSDLP, dan peta kawasan hutan dan konservasi perairan dari KLHK. Penetapan komoditas unggulan didasarkan atas Location Quotient dan Shift Share Analysis. Penetapan lahan potensial merujuk kepada metode Evaluasi Kesesuaian Lahan FAO. Perumusan rencana pengembangan lahan pertanian tanaman pangan menggunakan prosedur seleksi dan skrining berdasarkan logika Boolean. Hasil penelitian ini menetapkan lima komoditas unggulan tanaman pangan dan lahan potensial yang sesuai untuk pengembangannya seluas $5.871 \mathrm{Ha}$ dari $7.324 \mathrm{Ha}$ yang tersedia dan terdiri atas rencana penggunaan lahan untuk padi (3.529 Ha), ketela pohon $(1.398 \mathrm{Ha})$, jagung $(657 \mathrm{Ha})$, kedelai $(187 \mathrm{Ha})$, dan ketela rambat $(100 \mathrm{Ha})$. Rencana pengembangan lahan pertanian untuk komoditas unggulan tersebut dikategorikan atas prioritas pertama dan kedua masing-masing seluas 147 dan $5.724 \mathrm{Ha}$.
\end{abstract}

\footnotetext{
${ }^{1}$ Korespondensi Penulis: Program Studi Magister Ilmu Perencanaan Wilayah,, Sekolah Pascasarjana Institut Pertanian Bogor, Bogor, Indonesia Email: suryanianhy99@yahoo.com
} 
Kajian Pengembangan Lahan Pertanian Tanaman Pangan Berbasis Komoditas Unggulan . .

Kata Kunci: jagung; kesesuaian lahan; ketersediaan lahan; padi; pengembangan komoditas

\begin{abstract}
Agriculture sector performs prominent role in the economy of Pinrang Regency. As the national food-estate area of South Sulawesi Province, RGDP agriculture sector of the regency increased from 4.72 to 7.94 trillion IDR in 2013-2017. This study aims to analyze food-crop agriculture land development based on primary commodities in Pinrang Regency, South Sulawesi. This study was conducted in twelve sub-districts in the regency's area from September 2018 to June 2019. Application of geospatial technology was expected to present new approach with more accurate and easily updated land development planning in the area. The research data consisted of primary field survey data and secondary data of spatial pattern map of RTRW 2012-2032 from Bappeda and food-crop harvested area and production from BPS Pinrang Regency, characteristics and existing land use map from BBPPSDLP, and forest and water conservation area map from KLHK. Primary commodities was detemined based on Location Quotient and Shift Share Analysis. Potential land arrangement was referred to FAO Land Suitability Evaluation. Land development plan was formulated using selection and screening procedure based on Boolean logic. Five primary commodities was determined with 5,871 Ha potential land suitable for their development out of 7,324 Ha available land that consisted of land uses planned for paddy (3,529 Ha), cassava (1,398 Ha), corn (657 Ha), soybean $(187 \mathrm{Ha})$, and sweet potato $(100 \mathrm{Ha})$. The land development plan for these commodities was categorized into the first (147 Ha) and second (5, 724 Ha) priority.
\end{abstract}

Keywords: corn; cassava; commodity development; land availability; land suitability; paddy

\title{
Pendahuluan
}

Kabupaten Pinrang termasuk salah satu kawasan lumbung pangan nasional di Provinsi Sulawesi Selatan. Produksi pertaniannya, khususnya padi sawah, senantiasa mengalami peningkatan, dari 512,3 ribu ton pada 2010 menjadi 578,5 dan 662,4 ribu ton pada 2012 dan 2015 (BPS, 2016). Nilai PDRB sektor pertaniannya meningkat dari 4,72 menjadi 7,94 trilyun rupiah pada 2013 dan 2017. Jumlah penduduknya menunjukkan peningkatan 73348 jiwa pada periode 2006-2016 (BPS Kabupaten Pinrang, 2017). Hal ini berimplikasi terhadap kebutuhan pangan yang juga terus meningkat, sementara pertumbuhan permukiman, perkotaan, industri, dan pariwisata juga meningkat dan berdampak terhadap peningkatan konversi lahan pertanian produktif.

Perubahan tutupan lahan ditandai oleh konversi atau alih fungsi penggunaan lahan (Nurry \& Anjasmara, 2014). Selama periode 2000-2018, konversi lahan di Kabupaten Pinrang mencapai $63710 \mathrm{Ha}$ atau 33\% dari luas wilayah, meliputi penggunaan lahan kebun campuran, lahan terbuka, permukiman, sawah, tambak, dan tegalan/ladang. Konversi lahan pertanian berpengaruh terhadap ketahanan pangan, sehingga perlu diupayakan memperoleh lahan potensial untuk memperluas lahan pertanian demi terpenuhinya kebutuhan pangan. Pengembangan lahan pertanian baru berbasis komoditas unggulan merupakan salah satu solusi dalam menangani masalah tersebut. Namun, perluasan lahan pertanian baru seringkali tidak tepat sasaran. Perluasan lahan pertanian memerlukan persyaratan teknis dan non teknis. Pemanfaatan lahan yang tidak sesuai dengan kemampuannya tidak akan optimal dan cenderung menurunkan kualitas lingkungan. Kemampuan suatu lahan dalam mendukung pemanfaatannya sangat bergantung kepada faktor-faktor dasar lahan, antara lain kondisi batuan/tanah, hidrologi, dan lingkungan lainnya (Susanto, Kharis, \& Khotimah, 2016). Pengembangan komoditas unggulan di suatu wilayah perlu mempertimbangkan kesesuaian lahan, baik kesesuaian lahan saat ini (aktual) maupun setelah dilakukan perbaikan (potensial). 
Salah satu masalah utama terkait sumber daya lahan di Indonesia adalah akurasi data lahan pertanian (Kementerian Pertanian, 2015), sehingga perbaikan akurasi data pada tahap awal perencanaan penggunaan lahan menjadi prioritas. Salah satunya dapat diupayakan melalui kegiatan audit lahan dengan pemetaan sebaran, luas dan jenis lahan. Aplikasi teknologi geospasial berbasis Sistem Informasi Geografis (SIG), khususnya penginderaan jauh, merupakan salah satu cara mempercepat proses analisis zonasi untuk pengembangan lahan pertanian baru dengan hasil yang lebih akurat dan mudah dimutakhirkan. Sugiantoro, Paloloang, \& Nursalam (2015) menggunakan SIG untuk mengindentifikasi lahan sawah yang memenuhi kriteria kawasan pertanian pangan berkelanjutan di Kabupaten Sigi bagian Selatan. Penggunaan citra satelit beresolusi spasial menengah dan analisis spasial multi-temporal sebagai aplikasi teknologi penginderaan jauh merupakan metode yang tepat untuk memperoleh data penggunaan lahan (Susiati \& Subagio, 2016). Mansaray, Huang, Zhang, Huang, \& Li (2017) melakukan pemetaan lahan padi sawah di wilayah urban Shanghai, China bagian Tenggara menggunakan citra Landsat 8. Penentuan komoditas unggulan beserta potensi ketersediaan lahan yang sesuai dengan mempertimbangkan berbagai aspek tersebut merupakan salah satu rujukan penting bagi pemerintah dalam pengembangan lahan pertanian baru yang berkelanjutan. Penelitian ini akan berfokus menentukan komoditas unggulan pada lahan pertanian tanaman pangan dengan bantuan aplikasi SIG. Oleh karena itu, penelitian ini bertujuan mengkaji pengembangan lahan pertanian berbasis komoditas unggulan tanaman pangan di Kabupaten Pinrang, Sulawesi Selatan.

\section{Metode Penelitian}

\section{Lokasi dan Waktu}

Penelitian dilakukan di dua belas kecamatan di wilayah Kabupaten Pinrang yang memiliki komoditas unggulan tanaman pangan, yaitu Kecamatan Suppa, Mattiro Sompe, Lanrisang, Mattiro Bulu, Watang Sawitto, Paleteang, Tiroang, Patampanua, Cempa, Duampanua, Batulappa dan Lembang. Penelitian dilaksanakan sejak September 2018 hingga Juni 2019.

\section{Metode Pengumpulan Data}

Pengumpulan data meliputi pengumpulan data primer dengan melakukan survei lapangan untuk mengidentifikasi jenis penggunaan lahan dan penyebaran kuesioner kepada narasumber yang memiliki pemahaman baik tentang dinamika perkembangan pembangunan di Kabupaten Pinrang. Pengumpulan data sekunder dilakukan dengan mengumpulkan data luas panen dan produksi tanaman pangan dari Badan Pusat Statistik (BPS) Kabupaten Pinrang, satuan peta lahan, karakteristik lahan, dan peta penggunaan lahan eksisting dari Balai Besar Penelitian dan Pengembangan Sumber Daya Lahan Pertanian (BBPPSDLP), peta pola ruang Rencana Tata Ruang Wilayah (RTRW) Kabupaten Pinrang 2012-2032 dari Badan Perencanaan Pembanunan Daerah (Bappeda) Kabupaten Pinrang, dan peta penunjukan kawasan hutan dan konservasi perairan dari Kementerian Lingkungan Hidup dan Kehutanan (KLHK).

\section{Metode Analisis}

Analisis data dilakukan dengan melakukan penetapan komoditas unggulan erdasarkan nilai Location Quotient (LQ) dan Shift Share Analysis (SSA), serta penetapan lahan berpotensi pengembangan dilakukan dengan menganalisis ketersediaan lahan 
sebagai dasar pemilihan wilayah pengembangan komoditas tanaman pangan yang dideliniasi dengan metode overlay. Kerangka analisis disajikan pada Gambar 1.

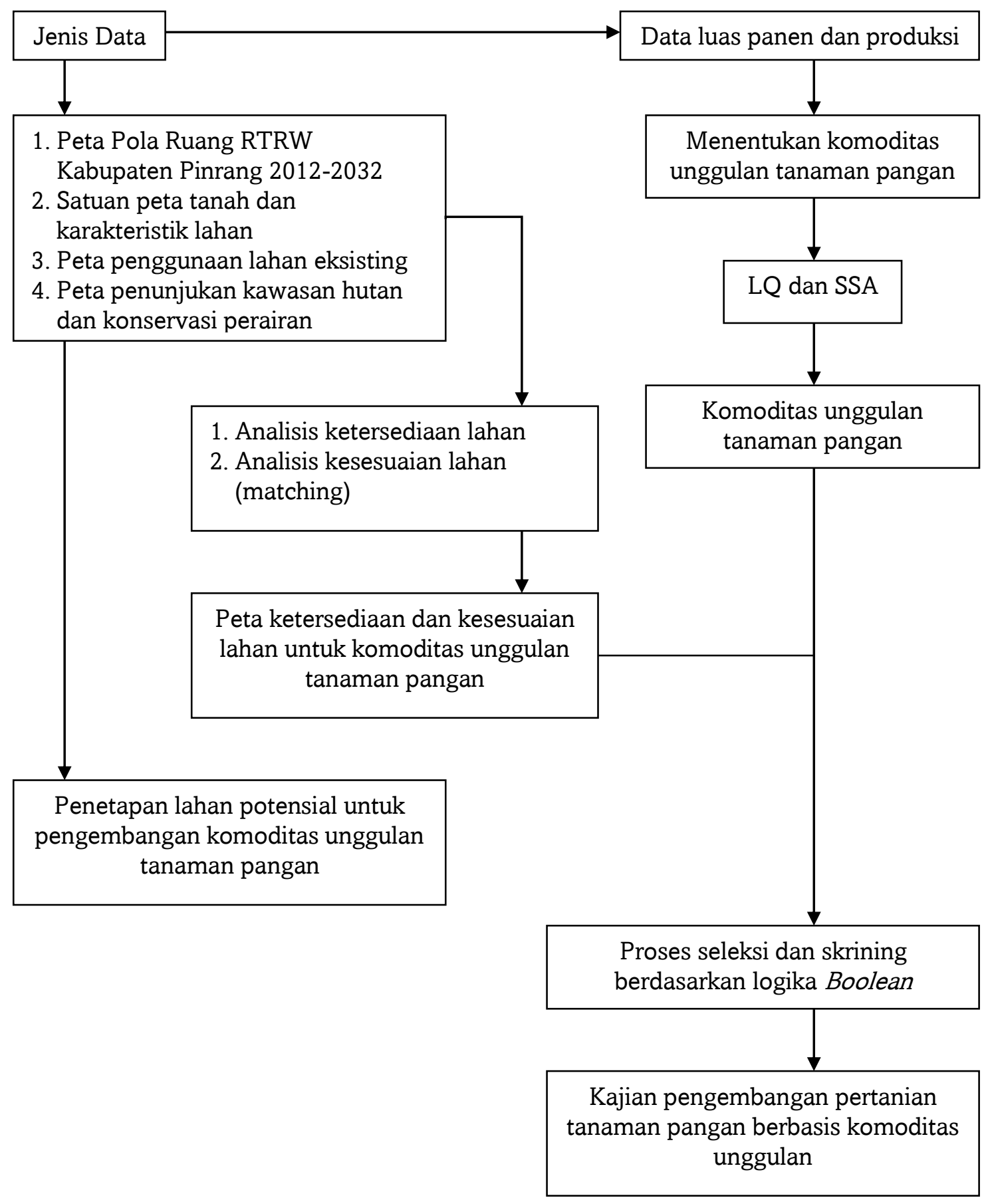

Gambar 1. Kerangka Kerja Penelitian 


\section{Penetapan Komoditas Unggulan Tanaman Pangan}

Jenis komoditas unggulan ditetapkan berdasarkan nilai Location Quotient (LQ) menurut Miller, Gibson, \& Wright (1991), sebagaimana yang ditampilkan pada persamaan (1).

$$
L Q=\frac{(p i / p t)}{(P i / P t)}
$$

Keterangan: $\mathrm{pi}=$ luas panen komoditas tanaman pangan "i" pada tingkat kecamatan; $\mathrm{pt}=$ luas panen total kelompok komoditas pada tingkat kecamatan; $\mathrm{Pi}=$ luas panen komoditas "i" pada tingkat kabupaten; $\mathrm{Pt}=$ luas panen total kelompok komoditas pada tingkat Kabupaten.

Pada suatu kecamatan, nilai LQ $>1,=1$ atau $<1$ masing-masing menunjukkan tingkat keunggulan komoditas sebagai sektor basis, swasembada, dan nonbasis. Selanjutnya data diolah dengan SSA untuk menentukan pergeseran struktur, kemampuan berkompetisi (competitiveness), dan kinerja aktivitas budidaya tanaman pangan di suatu kecamatan dibandingkan dengan referensi (wilayah Kabupaten Pinrang) dalam dua titik waktu. Persamaan SSA ditampilkan pada persamaan (2), sebagai berikut:

$$
S S A=\left(\frac{X . .(t 1)}{X . .(t 0)}-1\right)+\left(\frac{X i(t 1)}{X i(t 0)}-\frac{X . .(t 1)}{X . .(t 0)}\right)+\left(\frac{X i j(t 1)}{X i j(t 0)}-\frac{X i(t 1)}{X i(t 0)}\right)
$$

Keterangan: $\mathrm{a}=$ komponen share; $\mathrm{b}=$ komponen proportional shift, $\mathrm{c}=$ komponen differential shift $(D S) ; \mathrm{X} . .=$ produksi total semua komoditas tanaman pangan di wilayah Kabupaten Pinrang; X.j = produksi total komoditas tanaman pangan tertentu di wilayah Kabupaten Pinrang; Xij = produksi total komoditas tanaman pangan tertentu di wilayah suatu kecamatan; $\mathrm{t} 0=$ titik tahun awal; $\mathrm{t} 1=$ titik tahun akhir; nilai $\mathrm{DS}>0$ dan SSA $>1$ menunjukkan suatu komoditas memiliki keunggulan kompetitif di antara komoditas lainnya.

Komoditas unggulan adalah komoditas andalan yang memiliki posisi strategis untuk dikembangkan di suatu wilayah (Hidayah, 2010). Pendekatan LQ dan SSA diterapkan dalam penentuan komoditas unggulan tanaman pangan di Kabupaten Bantul, Yogyakarta (Mulyono \& Munibah, 2016) dan Kabupaten Pasaman, Sumatera Barat (Malinda, 2015). Menurut Masniadi, Suman, \& Sasongko (2012), komoditas dengan nilai LQ tertinggi menunjukkan komoditas tersebut lebih unggul secara komparatif dibandingkan komoditas lainnya. Keunggulan suatu komoditas juga perlu dievaluasi tingkat kompetitifnya berdasarkan hasil SSA. Menurut Baransano, Putri, Achsani, \& Kolopaking (2016), SSA merupakan salah satu dari beberapa teknik analisis untuk memahami pergeseran struktur aktivitas di suatu lokasi dibandingkan wilayah referensi yang lebih luas dalam dua titik waktu. Hasil SSA dapat menggambaran penyebab terjadinya pertumbuhan suatu aktivitas di suatu wilayah (Keratorop, Widiatmaka, \& Suwardi, 2016).

\section{Analisis Lahan Berpotensi Pengembangan}

Lahan berpotensi pengembangan ditetapkan dengan menganalisis ketersediaan lahan sebagai dasar pemilihan wilayah pengembangan untuk komoditas tanaman pangan yang didelineasi dengan metode overlay peta pola ruang, peta penunjukan kawasan hutan dan konservasi perairan, serta peta penggunaan lahan, termasuk lahan terbuka, semak belukar, 
dan tegalan/ladang. Dari tahapan ini diperoleh sebaran dan luas lahan pengembangan. Selanjutnya dilakukan analisis potensi sumber daya lahan, yang lebih menekankan pada kesesuaian lahan tersedia untuk pengembangan komoditas unggulan yang layak dikembangkan menurut metode Evaluasi Kesesuaian Lahan FAO (Sitorus, 2004; Widiatmaka ; Hardjowigeno, 2007) .Penetapan lahan berpotensi pengembangan dilakukan dengan menganalisis ketersediaan lahan sebagai dasar pemilihan wilayah pengembangan komoditas tanaman pangan yang didelineasi dengan metode overlay peta pola ruang, peta penunjukan kawasan hutan dan konservasi perairan, serta peta penggunaan lahan, termasuk lahan terbuka, semak belukar, dan tegalan/ladang. Dari tahapan ini diperoleh sebaran dan luas lahan pengembangan. Selanjutnya dilakukan analisis potensi sumber daya lahan yang lebih menekankan pada kesesuaian lahan tersedia untuk pengembangan komoditas unggulan yang layak untuk dikembangkan menurut metode Evaluasi Kesesuaian Lahan Food and Agriculture Organization (FAO) (Sitorus, 2004; Widiatmaka \& Hardjowigeno, 2007).

Pendekatan faktor pembatas digunakan untuk menetapkan kesesuaian lahan pada tingkat kelas. Metode ini membagi lahan berdasarkan jumlah dan intensitas faktor pembatas lahan. Faktor pembatas lahan adalah penyimpangan dari kondisi optimal suatu karakteristik dan kualitas lahan yang memberikan pengaruh buruk untuk penggunaan lahan tertentu. Dalam metode ini, faktor pembatas lahan dibagi ke dalam empat tingkatan: (a) 0 (tanpa pembatas), digolongkan ke dalam kelas S1 (Sesuai), (b) 1 (pembatas ringan), digolongkan ke dalam kelas S1 (Sesuai), (c) 2 (pembatas sedang), digolongkan ke dalam kelas S2 (Cukup Sesuai), (d) 3 (pembatas berat), digolongkan ke dalam kelas S3 (Sesuai Marginal), dan (e) 4 (pembatas sangat berat), digolongkan ke dalam kelas N1 atau N2 (Tidak Sesuai) (Sys, Van Ranst, \& Debaveye, 1991). Pendekatan faktor pembatas dalam evaluasi kesesuaian lahan untuk padi sawah dilakukan di Kecamatan Hamparan Perak, Kabupaten Deli Serdang (Nora, Rauf, \& Elfiati, 2015) dan di Desa Bakaran Baru, Kecamatan Sei Bamban, Kabupaten Serdang Bedagai, Provinsi Sumatera Utara (Tampubolon, Razali, \& Guchi, 2015).

Penentuan Parameter dan Kriteria Lahan Prioritas Pengembangan Pertanian Berbasis Komoditas Unggulan

Parameter dan penentuan lahan pengembangan didasarkan atas kesesuaian lahan untuk komoditas unggulan. Pengembangan pertanian diarahkan pada lahan potensial yang sesuai untuk budidaya komoditas unggulan tanaman pangan yang ditetapkan. Pengembangan tanaman pangan berbasis komoditas unggulan dilakukan dengan proses seleksi dan skrining berdasarkan logika Boolean. Dalam proses ini digunakan parameter ketersediaan lahan, luas hamparan, aksesibilitas (jarak dari jalan), dan kesesuaian lahan dengan dua nilai kriteria yang membagi hasil arahan menjadi Prioritas 1 dan Prioritas 2 (Tabel 1).

Tabel 1. Parameter dan Kriteria Lahan untuk Prioritas Pengembangan Pertanian Berbasis Komoditas Unggulan Tanaman Pangan di Kabupaten Pinrang

\begin{tabular}{clll}
\hline \multirow{2}{*}{ No. } & \multicolumn{1}{c}{ Parameter } & \multicolumn{1}{c}{ Prioritas } \\
\cline { 3 - 4 } & \multicolumn{1}{c}{ Prioritas 1 } & \multicolumn{1}{c}{ Prioritas 2 } \\
\hline 1. & Ketersediaan Lahan & Tersedia & Tersedia \\
2. & Luas Hamparan & $>5 \mathrm{ha}$ & $<5 \mathrm{ha}$ \\
3. & Aksesibilitas (Jarak dari Jalan) & $<1 \mathrm{Km}$ & $>1 \mathrm{Km}$ \\
4. & Kesesuaian Lahan & $\mathrm{S} 1, \mathrm{~S} 2$ & $\mathrm{~S} 3$ \\
\hline
\end{tabular}




\section{Hasil dan Pembahasan}

\section{Komoditas Unggulan Tanaman Pangan}

Berdasarkan nilai LQ dan hasil SSA, komoditas unggulan tanaman pangan di Kabupaten Pinrang ditetapkan terdiri atas padi, jagung, ketela pohon, kedelai, dan ketela rambat. Kelima komoditas tersebut memiliki nilai LQ $>1$ serta Nilai DS $>0$ dan SSA $>1$. Selain sebagai pangan pokok masyarakat, kelima komoditas tersebut merupakan unggulan di 9 kecamatan karena memiliki luas sawah yang memadai dan didukung oleh sistem pengairan/irigasi yang baik. Kecamatan Paleteang, Watang Sawitto, dan Mattiro Sompe tidak memiliki komoditas unggulan, sehingga wilayahnya tidak termasuk dalam perencanaan pengembangan. Hasil penetapan komoditas unggulan untuk tiap kecamatan di Kabupaten Pinrang disajikan pada Tabel 2.

Komoditas yang memiliki keunggulan berarti juga memiliki efisiensi finansial (Yustian, Sudadi, \& Ardiansyah, 2016). Ningsih (2010) berpendapat bahwa analisis dan penentuan komoditas unggulan daerah merupakan salah satu kunci pengembangan ekonomi secara tepat sasaran.

Tabel 2. Komoditas Unggulan Tanaman Pangan per Kecamatan di Kabupaten Pinrang

\begin{tabular}{|c|c|c|c|}
\hline Kecamatan & $\begin{array}{c}\text { Komoditas Unggulan } \\
(\mathrm{LQ}>1 ; \text { DS }>0 ; \text { SSA }>1)\end{array}$ & $\begin{array}{c}\text { Komoditas } \\
\text { Unggulan Utama }\end{array}$ & $\begin{array}{c}\text { Komoditas Unggulan } \\
\text { Penunjang }\end{array}$ \\
\hline Cempa & Padi & Padi & - \\
\hline Duampanua & Padi & Padi & - \\
\hline Lanrisang & Padi & Padi & - \\
\hline Patampanua & Padi & Padi & - \\
\hline Tiroang & Padi & Padi & - \\
\hline Batu Lappa & Jagung & Jagung & - \\
\hline Suppa & $\begin{array}{l}\text { Ketela Rambat, Ketela } \\
\text { Pohon, Jagung }\end{array}$ & Ketela Rambat & Ketela Pohon, Jagung \\
\hline Mattiro Bulu & $\begin{array}{l}\text { Ketela Pohon, Kacang } \\
\text { Tanah, Padi }\end{array}$ & Ketela Pohon & Kacang Tanah, Padi \\
\hline Lembang & $\begin{array}{l}\text { Kedelai, Kacang Hijau, } \\
\text { Kacang Tanah, Jagung }\end{array}$ & Kedelai & $\begin{array}{l}\text { Kacang Hijau, Kacang } \\
\text { Tanah, Jagung }\end{array}$ \\
\hline Mattiro Sompe $\left.{ }^{*}\right)$ & - & - & - \\
\hline Paleteang*) & - & - & - \\
\hline Watang Sawitto*) & - & - & - \\
\hline
\end{tabular}

\section{Potensi Lahan untuk Pengembangan Komoditas Unggulan Tanaman Pangan}

\section{Ketersediaan Lahan}

Dalam penentuan kawasan baru untuk pengembangan pertanian, selain komoditas unggulan juga perlu didasarkan atas hasil analisis ketersediaan lahan yang sesuai untuk mendukung pengembangan komoditas tersebut (commodity-driven). Berdasarkan kedua hal tersebut, pola ruang yang ditetapkan tersedia untuk pengembangan komoditas unggulan tanaman pangan di Kabupaten Pinrang adalah kawasan dengan peruntukan lahan basah (sawah) dan lahan kering (tegalan/ladang), masing-masing seluas $4.219 \mathrm{Ha}$ dan $3.805 \mathrm{Ha}$. Ketersediaan lahan per kecamatan untuk pengembangan komoditas unggulan tanaman pangan di Kabupaten Pinrang disajikan pada Tabel 3. 
Tabel 3. Ketersediaan Lahan untuk Pengembangan Komoditas Unggulan Tanaman Pangan di Kabupaten Pinrang

\begin{tabular}{|c|c|c|c|}
\hline \multirow[b]{2}{*}{ Kecamatan } & \multirow{2}{*}{$\begin{array}{c}\text { Luas } \\
\text { Kecamatan } \\
\text { (Ha) } \\
\end{array}$} & \multicolumn{2}{|c|}{ Luas Lahan Tersedia } \\
\hline & & (Ha) & $(\%)$ \\
\hline Kecamatan yang memiliki komoditas unggulan & 176.852 & 7.324 & 3,73 \\
\hline Batu Lappa & 15.899 & 697 & 0,36 \\
\hline Cempa & 9.030 & 156 & 0,08 \\
\hline Duampanua & 29.186 & 2.573 & 1,31 \\
\hline Lanrisang & 7.301 & 190 & 0,10 \\
\hline Lembang & 73.309 & 455 & 0,23 \\
\hline Mattiro Bulu & 13.249 & 1.556 & 0,79 \\
\hline Patampanua & 13.685 & 904 & 0,46 \\
\hline Suppa & 7.420 & 218 & 0,11 \\
\hline Tiroang & 7.773 & 575 & 0,29 \\
\hline Kecamatan yang tidak memiliki komoditas unggulan & 19.325 & 865 & 0,44 \\
\hline Mattiro Sompe & 9.699 & - & 0,00 \\
\hline Paleteang & 3.729 & 715 & 0,36 \\
\hline Watang Sawitto & 5.897 & 150 & 0,08 \\
\hline Jumlah & 196.177 & 8.189 & 4,17 \\
\hline
\end{tabular}

\section{Kesesuaian Lahan Tersedia}

Hasil analisis kesesuaian lahan untuk budidaya komoditas unggulan tanaman pangan di Kabupaten Pinrang yang disajikan pada Tabel 4 dan Gambar 2 menunjukkan bahwa dari lahan berpotensi pengembangan yang tersedia tidak ada yang berkelas kesesuaian S1 (sesuai) dan yang terluas untuk masing-masing dari kelima komoditas unggulan berada pada kelas S3 (sesuai marginal). Drainase dan kemiringan lereng atau topografi merupakan faktor pembatas dominan yang mempengaruhi tingkat kesesuaian lahan untuk padi sawah.

\section{Pengembangan Pertanian Tanaman Pangan Berbasis Komoditas Unggulan}

\section{Penggunaan Lahan Potensial}

Luas dan sebaran penggunaan lahan potensial atau yang tersedia dan sesuai untuk pengembangan komoditas unggulan tanaman pangan di Kabupaten Pinrang yang disusun berdasarkan komoditas unggulan utama (Tabel 2) untuk tiap kecamatan disajikan pada Tabel 5 dan Gambar 2. Penggunaan lahan yang dapat dimanfatkan untuk komoditas unggulan utama padi seluas 3.529 Ha berada di kecamatan Cempa, Duampanua, Lanrisang, Patampanua, dan Tiroang; untuk ketela pohon seluas 1.398 Ha di kecamatan Mattiro Bulu; untuk jagung seluas $657 \mathrm{Ha}$ di kecamatan Batu Lappa; untuk kedelai seluas 187 Ha di kecamatan Lembang; dan untuk ketela rambat seluas $100 \mathrm{Ha}$ di kecamatan Suppa. Rencana penggunaan lahan yang didominasi padi diarahkan di kecamatan Cempa, Duampanua, Lanrisang, Patampanua, dan Tiroang, yang terluas di kecamatan Duampanua seluas $1.708 \mathrm{Ha}$.

Pembangunan suatu daerah dan pengembangan wilayahnya tidak terlepas dari pembangunan sektor pertanian (Faizah \& Santoso, 2013), yang sangat ditentukan oleh kualitas lahannya (Li et al., 2013). Fungsi utama dari kajian penggunaan lahan ini adalah memberikan arahan dalam proses pengambilan keputusan tentang penggunaan suatu lahan, sehingga sumber daya lahan tersebut dan lingkungannya ditempatkan pada penggunaan yang paling menguntungkan/efisien bagi manusia, dan dalam waktu bersamaan mengkonservasinya untuk penggunaan pada masa yang akan datang (Sitorus, 2004). 
Tabel 4. Kesesuaian Lahan untuk Komoditas Unggulan Tanaman Pangan di Kabupaten Pinrang

\begin{tabular}{|c|c|c|c|c|c|c|c|c|c|c|c|c|}
\hline \multirow{2}{*}{$\begin{array}{l}\text { Komoditas } \\
\text { Unggulan }\end{array}$} & \multirow{2}{*}{$\begin{array}{c}\text { Kesesuaian } \\
\text { Lahan }{ }^{*}\end{array}$} & \multicolumn{9}{|c|}{ Luas Lahan per Kecamatan (Ha) $\left.{ }^{* *}\right)$} & \multicolumn{2}{|c|}{ Jumlah } \\
\hline & & 1 & 2 & 3 & 4 & 5 & 6 & 7 & 8 & 9 & (Ha) & $(\%)$ \\
\hline \multirow{5}{*}{ Padi } & & 697 & 156 & 2573 & 190 & 455 & 1.556 & 904 & 218 & 575 & 7.324 & 100 \\
\hline & $\mathrm{S} 2$ & 8 & - & 134 & - & 131 & - & - & - & - & 273 & 4 \\
\hline & S3 & 649 & 156 & 1574 & 190 & 56 & 1398 & 900 & 100 & 575 & 5.598 & 76 \\
\hline & $\mathrm{N}$ & 40 & - & 865 & - & 268 & 158 & 4 & 118 & - & 1.453 & 20 \\
\hline & & 697 & 156 & 2.573 & 190 & 455 & 1.556 & 904 & 218 & 575 & 7.324 & 100 \\
\hline \multirow[t]{3}{*}{ Jagung } & S3 & 657 & 156 & 1708 & 190 & 187 & 1398 & 900 & 100 & 575 & 5.871 & 80 \\
\hline & $\mathrm{N}$ & 40 & - & 865 & - & 268 & 158 & 4 & 118 & - & 1.453 & 20 \\
\hline & & 697 & 156 & 2.573 & 190 & 455 & 1.556 & 904 & 218 & 575 & 7.324 & 100 \\
\hline \multirow[t]{4}{*}{ Ketela Pohon } & $\mathrm{S} 2$ & - & - & 107 & - & - & - & - & - & - & 107 & 1 \\
\hline & S3 & 657 & 156 & 1.601 & 190 & 187 & 1398 & 900 & 100 & 575 & 5.765 & 79 \\
\hline & $\mathrm{N}$ & 40 & - & 865 & - & 268 & 158 & 4 & 118 & - & 1.453 & 20 \\
\hline & & 697 & 156 & 2.573 & 190 & 455 & 1.556 & 904 & 218 & 575 & 7.324 & 100 \\
\hline \multirow[t]{4}{*}{ Kedelai } & $\mathrm{S} 2$ & - & - & 107 & - & - & - & - & - & - & 107 & 1 \\
\hline & S3 & 657 & 156 & 1601 & 190 & 187 & 1398 & 900 & 100 & 575 & 5.765 & 79 \\
\hline & $\mathrm{N}$ & 40 & - & 865 & - & 268 & 158 & 4 & 118 & - & 1.453 & 20 \\
\hline & & 697 & 156 & 2.573 & 190 & 455 & 1.556 & 904 & 218 & 575 & 7.324 & 100 \\
\hline Ketela & $\mathrm{S} 2$ & 52 & 101 & 262 & 113 & 31 & 164 & 148 & 14 & - & 885 & 12 \\
\hline \multirow[t]{2}{*}{ Rambat } & S3 & 605 & 55 & 1446 & 77 & 156 & 1234 & 752 & 86 & 575 & 4.986 & 68 \\
\hline & $\mathrm{N}$ & 40 & - & 865 & - & 268 & 158 & 4 & 118 & - & 1.453 & 20 \\
\hline
\end{tabular}

${ }^{*}$ S2 Cukup Sesuai, S3 Sesuai Marginal, N Tidak Sesuai

**) 1 Batu Lappa, 2 Cempa, 3 Duampanua, 4 Lanrisang, 5 Lembang, 6 Mattiro Bulu, 7 Patampanua, 8 Suppa, 9 Tiroang

Tabel 5. Kajian Penggunaan Lahan untuk Komoditas Unggulan Utama di Kabupaten Pinrang

\begin{tabular}{|c|c|c|c|c|c|c|c|c|c|c|c|c|}
\hline \multirow{2}{*}{$\begin{array}{l}\text { Komoditas } \\
\text { Unggulan } \\
\text { Utama }\end{array}$} & \multirow{2}{*}{$\begin{array}{c}\text { Kesesuaian } \\
\text { Lahan *) }\end{array}$} & \multicolumn{9}{|c|}{ Kecamatan **) } & \multicolumn{2}{|c|}{ Jumlah } \\
\hline & & 1 & 2 & 3 & 4 & 5 & 6 & 7 & 8 & 9 & (Ha) & $(\%)$ \\
\hline & & 657 & 156 & 1.708 & 190 & 187 & 1.398 & 900 & 100 & 575 & 3.529 & 60,1 \\
\hline \multirow{3}{*}{ Padi } & $\mathrm{S} 2$ & - & - & 134 & - & - & - & - & - & - & 134 & 2,3 \\
\hline & S3 & - & 156 & 1.574 & 190 & - & - & 900 & - & 575 & 3.395 & 57,8 \\
\hline & & 657 & 156 & 1.708 & 190 & 187 & 1.398 & 900 & 100 & 575 & 657 & 11,2 \\
\hline \multirow[t]{2}{*}{ Jagung } & S3 & 657 & - & - & - & - & - & - & - & - & 657 & 11,2 \\
\hline & & 657 & 156 & 1.708 & 190 & 187 & 1.398 & 900 & 100 & 575 & 1.398 & 23,8 \\
\hline \multirow{2}{*}{$\begin{array}{l}\text { Ketela } \\
\text { Pohon }\end{array}$} & $\mathrm{S} 3$ & - & - & - & - & - & 1.398 & - & - & - & 1.398 & 23,8 \\
\hline & & 657 & 156 & 1.708 & 190 & 187 & 1.398 & 900 & 100 & 575 & 187 & 3,2 \\
\hline \multirow[t]{2}{*}{ Kedelai } & $\mathrm{S} 3$ & - & - & - & - & 187 & - & - & - & - & 187 & 3,2 \\
\hline & & 657 & 156 & 1.708 & 190 & 187 & 1.398 & 900 & 100 & 575 & 100 & 1,7 \\
\hline Ketela & $\mathrm{S} 2$ & - & - & - & - & - & - & - & 14 & - & 14 & 0,2 \\
\hline Rambat & S3 & - & - & - & - & - & - & - & 86 & - & 86 & 1,5 \\
\hline Jumlah & & & & & & & & & & & 5.871 & 100 \\
\hline
\end{tabular}

$\left.{ }^{*}\right)$ S2 Cukup Sesuai, S3 Sesuai Marginal
$\left.{ }^{* *}\right)$ 1 Batu Lappa, 2 Cempa, 3 Duampanua, 4 Lanrisang, 5 Lembang, 6 Mattiro Bulu, 7 Patampanua, 8 Suppa, 9 Tiroang

Dalam penelitian ini, proses perencanaan pengembangan lahan pertanian dilakukan dengan pendekatan baru memanfaatkan teknologi geospasial dan SIG dengan terlebih 
dahulu menetapkan komoditas unggulan tanaman pangan yang akan dikembangkan pada lahan potensial, yaitu lahan yang tersedia menurut pola ruang RTRW, sesuai untuk budidaya komoditas unggulan dengan tingkat S2 dan/atau S3, memiliki aksesibilitas $1 \mathrm{~km}$ atau kurang dari jalan, dan luas hamparan 5 ha atau lebih, guna mendapatkan hasil yang optimal. Menurut Direktorat Jenderal Prasarana dan Sarana Pertanian, Kementerian Pertanian (2018), salah satu kriteria lokasi yang dapat diusulkan dalam program pengembangan lahan sawah baru adalah berada dalam satu hamparan dengan luasan minimal 5 ha. Hasil perencanaan pengembangan lahan pertanian tanaman pangan berbasis komoditas unggulan di Kabupaten Pinrang disajikan pada Tabel 6 dan Gambar 3, yang terdiri atas prioritas 1 seluas $147 \mathrm{Ha}$ untuk komoditas padi seluas $134 \mathrm{Ha}$ dan ketela rambat seluas $13 \mathrm{Ha}$, serta prioritas 2 seluas $5.724 \mathrm{Ha}$ untuk komoditas padi seluas $3.395 \mathrm{Ha}$, ketela pohon $1.398 \mathrm{Ha}$, jagung $657 \mathrm{Ha}$, kedelai $187 \mathrm{Ha}$, dan ketela rambat $87 \mathrm{Ha}$.

Lahan pengembangan prioritas 1 memiliki kelas kesesuaian lahan S2 dengan aksesibilitas $\leq 1 \mathrm{~km}$ dan luas hamparan $\geq 5$ ha. Lahan pengembangan prioritas 2 juga memiliki aksesibilitas $\leq 1 \mathrm{~km}$ dan luas hamparan melebihi $\geq 5$ ha namun kelas kesesuaian lahannya S3. Unit lahan yang tergolong bukan prioritas untuk dikembangkan disebabkan oleh kesesuaian lahan kelas $\mathrm{N}$ akibat faktor pembatas sangat berat. Meskipun masih dimungkinkan untuk diatasi tetapi tidak dapat dilakukan dengan tingkat pengetahuan saat ini dengan biaya yang rasional (FAO, 1976). Ketersediaan infrastruktur untuk pengadaan input dan penyaluran output usaha tani merupakan salah satu aspek perencanaan pengembangan yang harus dipertimbangkan (Muslim, 2014).

Tabel 6. Prioritas Pengembangan Pertanian Tanaman Pangan Berbasis Komoditas Unggulan di Kabupaten Pinrang

\begin{tabular}{|c|c|c|c|c|c|}
\hline \multirow{3}{*}{ Komoditas Unggulan } & \multirow{3}{*}{ Kecamatan } & \multicolumn{2}{|c|}{ Prioritas } & \multirow{2}{*}{\multicolumn{2}{|c|}{ Jumlah }} \\
\hline & & 1 & 2 & & \\
\hline & & (Ha) & (Ha) & (Ha) & $(\%)$ \\
\hline \multirow[t]{5}{*}{ Padi } & Cempa & - & 156 & 156 & 2,7 \\
\hline & Duampanua & 134 & 1.574 & 1.708 & 29,1 \\
\hline & Lanrisang & - & 190 & 190 & 3,2 \\
\hline & Patampanua & - & 900 & 900 & 15,3 \\
\hline & Tiroang & - & 575 & 575 & 9,8 \\
\hline Jagung & Batu Lappa & - & 657 & 657 & 11,2 \\
\hline Ketela Rambat & Suppa & 13 & 87 & 100 & 1,7 \\
\hline Ketela Pohon & Mattiro Bulu & - & 1.398 & 1.398 & 23,8 \\
\hline Kedelai & Lembang & - & 187 & 187 & 3,2 \\
\hline Jumlah & & 147 & 5.724 & 5.871 & 100 \\
\hline
\end{tabular}



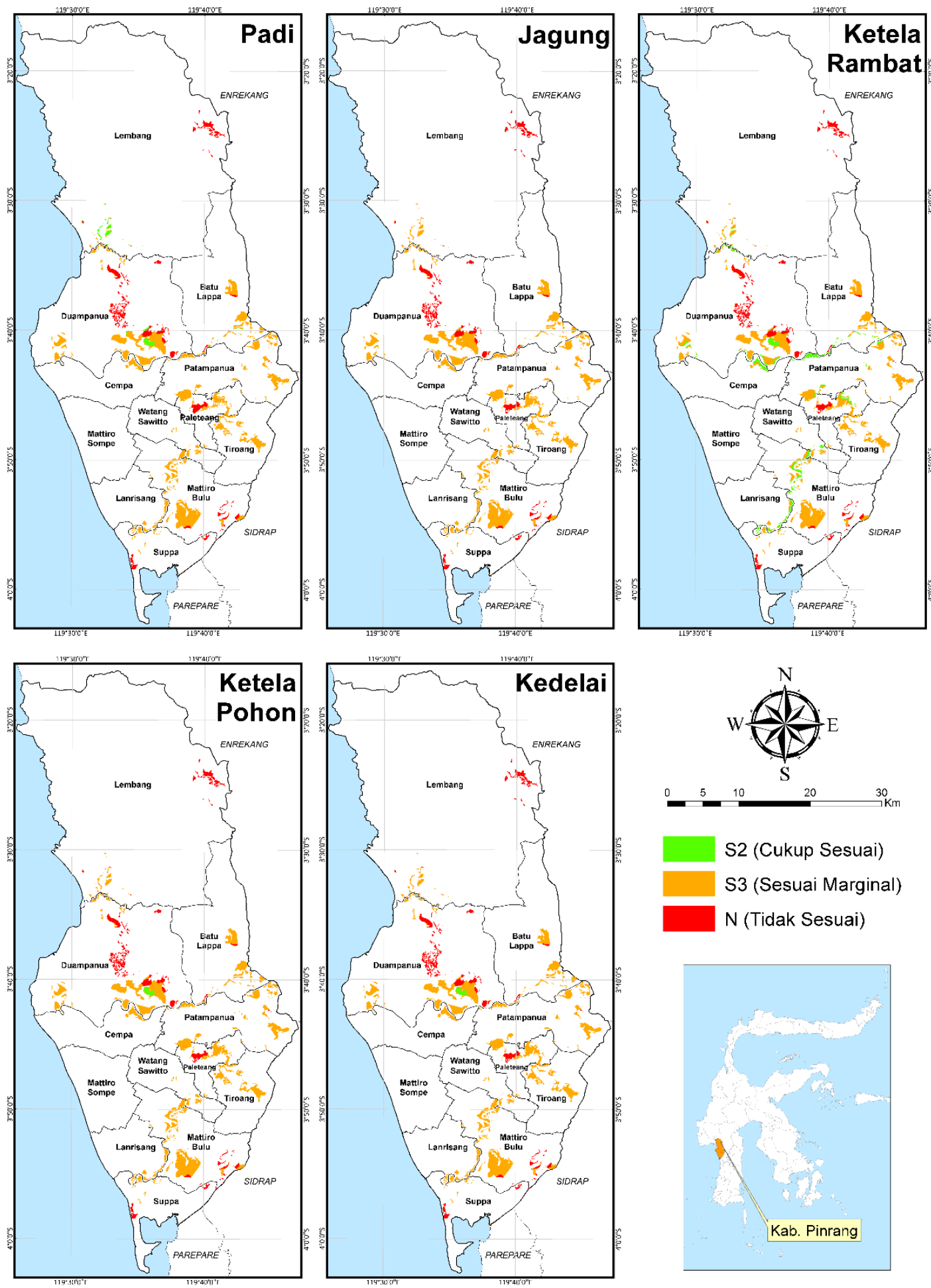

S2 (Cukup Sesuai)

S3 (Sesuai Marginal)

N (Tidak Sesuai)

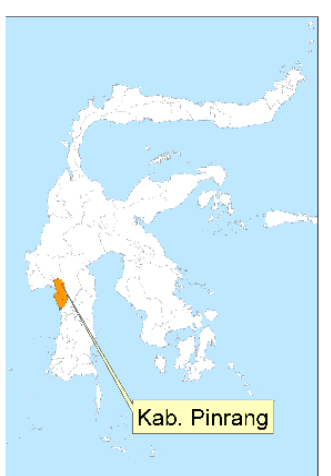

Gambar 2. Kesesuaian Lahan Tersedia untuk Pengembangan Komoditas Unggulan Tanaman Pangan di Kabupaten Pinrang 


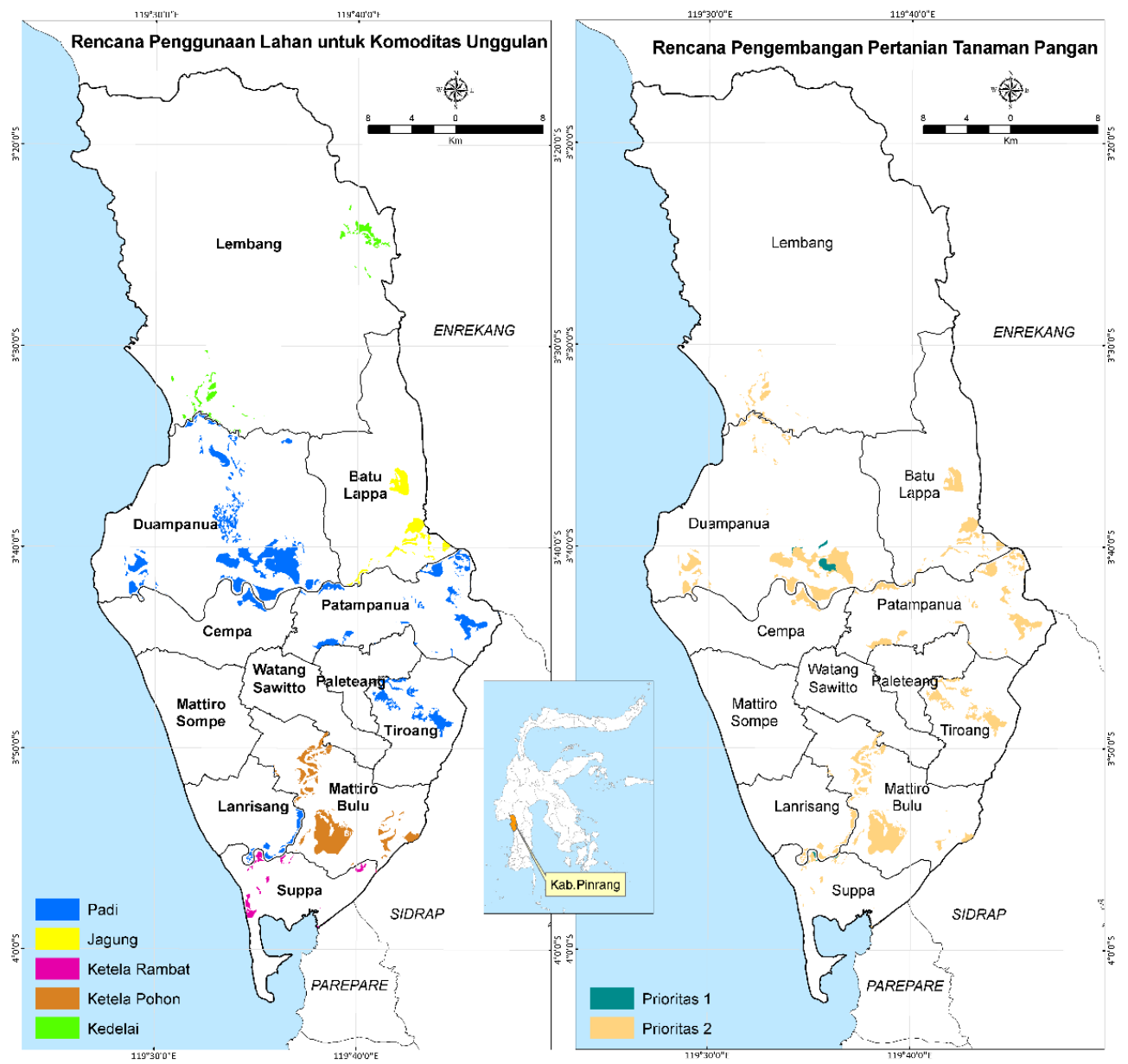

(a)

(b)

\section{Gambar 3. Rencana Penggunaan Lahan untuk (a) Komoditas Unggulan Tanaman Pangan dan (b) Prioritas Rencana Pengembangan Pertanian Tanaman Pangan di Kabupaten Pinrang}

\section{Kesimpulan}

Aplikasi teknologi geospasial berbasis Sistem Informasi Geografis dalam perencanaan pengembangan lahan pertanian di Kabupaten Pinrang menghasilkan lima komoditas unggulan tanaman pangan. Lahan tersedia yang sesuai untuk pengembangan kelima komoditas tersebut seluas $5.871 \mathrm{Ha}$ yang terdistribusi atas rencana penggunaan lahan untuk budidaya padi (3.529 Ha), ketela pohon (1.398 Ha), jagung (657 Ha), kedelai (187 Ha), dan ketela rambat (100 Ha). Rencana pengembangan lahan tersebut terdiri atas prioritas 1 pada lahan dengan tingkat kesesuaian S2 (cukup sesuai) seluas $147 \mathrm{Ha}$ dan prioritas 2 pada lahan dengan tingkat kesesuaian S3 (sesuai marginal) seluas $5724 \mathrm{Ha}$, keduanya dengan aksesibilitas kurang $1 \mathrm{~km}$ dari jalan dan luas hamparan lebih 5 hektar. Hasil penelitian ini, dalam bentuk rencana spasial pengembangan lahan pertanian, akan berguna bagi Pemerintah Daerah Kabupaten Pinrang dalam perencanaan pengembangan wilayah pertanian dan, dalam bentuk pendekatan dan proses kajian perencanaan, akan menambah akumulasi pengetahuan empirik dalam Ilmu Perencanaan Wilayah serta dapat digunakan sebagai rujukan bagi para peneliti berikutnya untuk pengembangannya. 


\section{Ucapan Terima Kasih}

Penulis pertama mengucapkan terimakasih kepada para narasumber yang telah memberikan pengetahuan dan pengalamannya sebagai salah satu dasar penetapan lokasi survei lapangan dalam penelitian ini.

\section{Daftar Pustaka}

Baransano, M. A., Putri, E. I. K., Achsani, N. A., \& Kolopaking, L. (2016). Peranan sektor unggulan sebagai salah satu faktor dalam mengurangi ketimpanan pembangunan wilayah di Provinsi Papua Barat. Jurnal Perencanaan Wilayah dan Kota, 272), 119-136. doi:10.5614/jrcp.2016.27.2.4.

BPS. (2016). Statistik Indonesia tahun 2016. Jakarta.

BPS Kabupaten Pinrang. (2017). Kabupaten Pinrang dalam angka tahun 2017. Pinrang.

Direktorat Jenderal Prasarana dan Sarana Pertanian, Kementerian Pertanian. (2018). Pedoman Teknis survei, investigasi calon petani-calon lokasi dan desain perluasan sawah. Direktorat Perluasan dan Perlindungan Lahan. Kementerian Pertanian.

Faizah, A. A., \& Santoso, E. B. (2013). Arahan pengembangan kawasan pertanian tanaman pangan di Kabupaten Sampang. Jurnal Teknik ITS, 2(2), 197-199. doi:10.12962/j23373539.v2i2.3926.

FAO. (1976). A framework for land evaluation (FAO Soils). Rome: Food and Agriculture Organization of the United Nations (FAO).

Hidayah, I. (2010). Analisis prioritas komoditas unggulan perkebunan daerah Kabupaten Buru. Agrika: Jurnal Ilmu-Ilmu Pertanian, 4(1), 1-8. doi:10.31328/ja.v4i1.143.

Kementerian Pertanian. (2015). Rencana Strategis Kementerian Pertanian Tahun 2015-2016. Jakarta: Kementerian Pertanian.

Keratorop, M., Widiatmaka, W., \& Suwardi, S. (2016). Arahan pengembangan komoditas unggulan pertanian tanaman pangan di Kabupaten Boven Digoel Provinsi Papua. Plano Madani: Jurnal Perencanaan Wilayah Dan Kota, 5(2), 143-157. doi:10.24252/planomadani.5.2.5.

Li, W., Zhang, Y., Wang, C., Mao, W., Hang, T., Chen, M., \& Zhang, B. (2013). How to evaluate the rice cultivation suitability? Asian Agricultural Research, 5(12), 59-64.

Malinda, Y. (2015). Analisis pembangunan wilayah berbasis komoditi unggulan Kabupaten Pasaman, Sumatera Barat. Economica: Jurnal Program Studi Pendidikan Ekonomi STKIP PGRI Sumatera Barat, 3(2), 219233. doi:10.22202/economica.2015.v3.i2.258.

Mansaray, L., Huang, W., Zhang, D., Huang, J., \& Li, J. (2017). Mapping rice fields in urban Shanghai, Southeast China, using sentinel-1A and landsat 8 datasets. Remote Sensing, 9(3), 257. doi:10.3390/rs9030257.

Masniadi, R., Suman, A., \& Sasongko, S. (2012). Analisis komoditas unggulan pertanian untuk pengembangan ekonomi daerah tertinggal di Kabupaten Sumbawa Barat. Journal of Innovation in Business and Economics, 3(1). doi:10.22219/jibe.v3i1.2228.

Miller, M. M., Gibson, L. J., \& Wright, N. G. (1991). Location quotient: A basic tool for economic development analysis. Economic Development Review, 9(2), 65-73.

Mulyono, J., \& Munibah, K. (2016). Pendekatan location quotient dan shift share analysis dalam penentuan komoditas unggulan tanaman pangan di Kabupaten Bantul. Jurnal Informatika Pertanian, 25(2), 221-239.

Muslim, C. (2014). Pengembangan lahan sawah (sawah bukaan baru) dan kendala pengelolaannya dalam pencapaian target surplus 10 juta ton beras tahun 2014. SEPA: Jurnal Sosial Ekonomi Pertanian Dan Agribisnis, 19(2), 257-267. doi:10.20961/sepa.v10i2.14134.

Ningsih, E. S. M. (2010). Analisis komoditi unggulan sektor pertanian Kabupaten Sukoharjo sebelum dan selama otonomi daerah. Universitas Sebelas Maret.

Nora, S., Rauf, A., \& Elfiati, D. (2015). Evaluasi kesesuaian lahan untuk tanaman lahan sawah di Kecamatan Hamparan Perak Kabupaten Deli. Jurnal Pertanian Tropik, 2(3), 347-348. doi:10.32734/jpt.v2i3.2943.

Nurry, A., \& Anjasmara, I. M. (2014). Kajian perubahan tutupan lahan Daerah Aliran Sungai Brantas bagian hilir menggunakan citra satelit multi temporal (Studi Kasus: Kali Porong, Kabupaten Sidoarjo). Geoid: Journal 
of Geodesy and Geomatics, 19(1), 70-74. doi:10.12962/j24423998.v10i1.694.

Sitorus, S. (2004). Evaluasi sumberdaya lahan: Edisi ketiga. Penerbit Tarsito (Edisi Keti). Bandung: Penerbit Tarsito.

Sugiantoro, D., Paloloang, A. K., \& Nursalam. (2015). Aplikasi Sistem Informasi Geografi untuk mengidentifikasi lahan pangan berkelanjutan pada areal persawahan di Kabupaten Sigi Bagian Selatan. Agrotekbis, 3(6), 662-668.

Susanto, A., Kharis, A., \& Khotimah, T. (2016). Sistem informasi geografis pemetaan lahan pertanian dan komoditi hasil panen Kabupaten Kudus. Jurnal Informatika, 192), 1233-1243.

Susiati, H., \& Subagio, H. (2016). Aplikasi penginderaan jauh dalam pemetaan penggunaan lahan detil tapak RDE, PUSPIPTEK Serpong. Jurnal Pengembangan Energi Nuklir, 18(2), 101-112. doi:10.17146/jpen.2016.18.2.3232.

Sys, C., Van Ranst, E., \& Debaveye, J. (1991). Land evaluation. Part II: methods in land evaluation. Agricultural publications nr. 7, GADC, Brussels, Belgium, 1991. Brussels: General Administration for Development Cooperation.

Tampubolon, K., Razali, \& Guchi, H. (2015). Evaluasi kesesuaian lahan tanaman padi sawah irigasi (Oryza sativa L.) di Desa Bakaran Batu Kecamatan Sei Bamban Kabupaten Serdang Bedagai. Agroekoteknologi, 3(2), 732-739.

Widiatmaka, \& Hardjowigeno, S. (2007). Evaluasi kesesuaian lahan \& perencanaan tata guna lahan. Yogyakarta: Gadjah Mada University Press.

Yustian, Y., Sudadi, U., \& Ardiansyah, M. (2016). Arahan dan strategi pengembangan lahan sawah di wilayah pesisir Provinsi Kalimantan Barat. Jurnal Ilmu Tanah dan Lingkungan, 16(1), 31-37. 